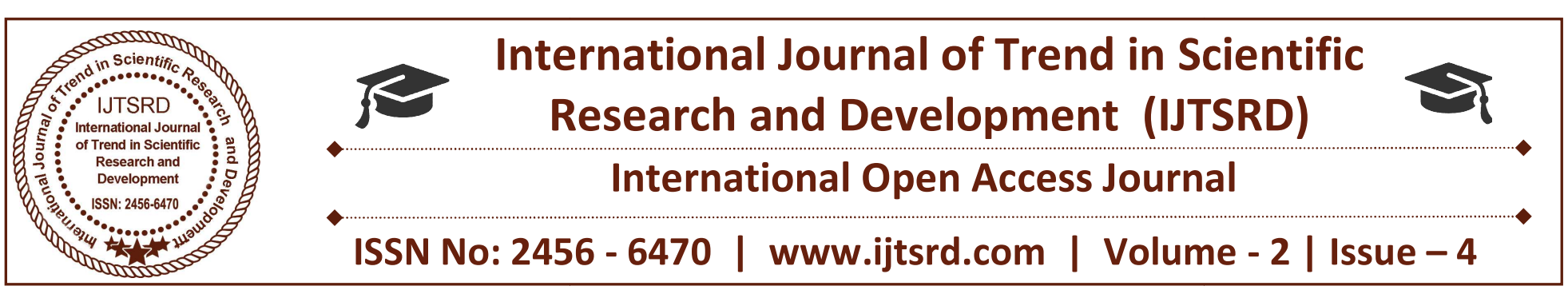

\title{
Dynamic Analysis of Multistory RCC Building Frame with Flat Slab and Grid Slab
}

\author{
Indrani $\mathbf{V}^{1}$, Shubha D. $\mathbf{K}^{2}$, Lavina E. $\mathbf{J}^{3}$ \\ ${ }^{1}$ MTech, Structural Engineering, ${ }^{2}$ Assistant Professor, ${ }^{3}$ Assistant Professor \\ ${ }^{1,2}$ Sahyadri College of Engineering \& Management, Mangalore, Karnataka, India \\ ${ }^{3}$ Vijaya Vitala Institute of Technology, Banglore, Karnataka, India
}

\begin{abstract}
Conventional R.C.C structure i.e flat slab, shear wall, column for different heights are modelled and analyzed for the different combinations of static loading with varying thicknesses of shear wall with varying height of multistoried building 1 . The comparison is made between the conventional R.C.C flat slab structure of 10,20 and 30 stories without shear wall. The comparison made between the conventional R.C.C flat slab structure of 10,20 and 30 stories with varying thicknesses of shear wall in multi - storied buildings have been provided at some particular locations .The main objective of analysis is to study the difference between fllat slab and grid slab and also comparision of shapes of rectangle square and hexagon which shapes is best in siesmic behaviour of analysis using etabs software.
\end{abstract}

Keywords: Flat slab, Shear walls, Plate Stresses, Flexibility, Lateral displacement, Storey drif

\section{INTRODUCTION}

\subsection{FLAT SLAB SYSTEM}

often thickened closed to supporting columns to provide adequate strength in shear and to reduce the amount of negative reinforcement in the Support regions. The thickened portion i.e. the projection below the slab is called drop or drop panel. In some cases, the section of column at top, as it meets the floor slab or a drop panel, is enlarged so as to increase primarily the perimeter of the critical section, for shear and hence, increasing the capacity of the slab for resisting twoway shear and to reduce negative bending moment at the support.

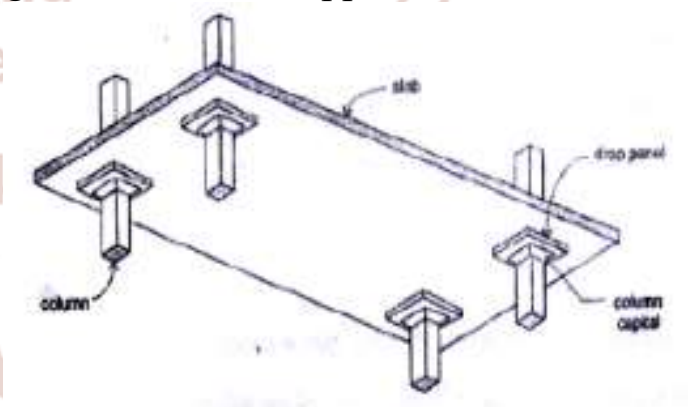

Figure-Flat slab system

The term flat slab means a reinforced concrete slab with or without drops, supported generally without beams, by columns with or without flared heads, A flat slab may be solid slab or may have recesses formed on the soffit so that a soffit comprises a series of ribs in two. directions. The recess may be formed of permanent or removable filler blocks. A reinforced concrete flat slab, also called as beamless slab, is a slab supported directly by columns without beams. A part of the slab bounded on each of the four sides by centerline of column is called panel. The flat slab is

\subsection{GRID SLAB SYSTEM}

Grid floor systems consisting of beams spaced at regular intervals in perpendicular directions, monolithic with slab. They are generally employed for architectural reasons for large rooms such as auditoriums, vestibules, theatre halls, show rooms of shops where column free space is required. Often the main requirement. The rectangular or square void formed in the ceiling is advantageously utilized for concealed architectural lighting. The sizes of the beams running in perpendicular directions are 
generally kept the same. Instead of rectangular beam grid, a diagonal.

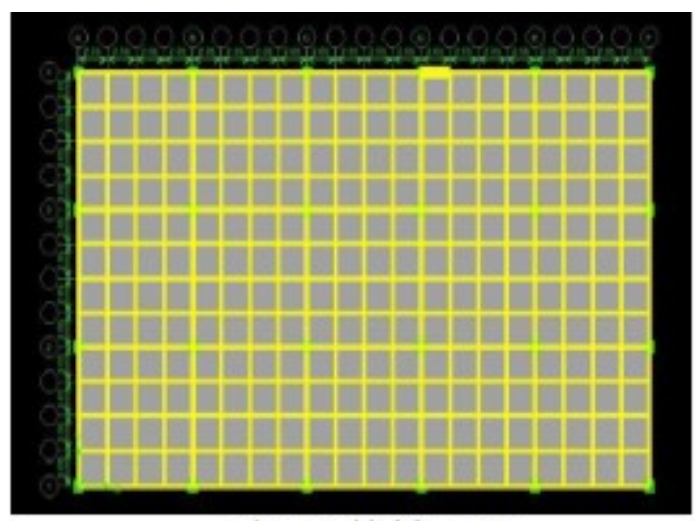

Figure-Grid slab system

\section{Literature survey}

Amit A. Sathwane studied that the among flat slab , flat slab with drop and grid slab which is economical for the nexus point opposite to vidhan bhavan and beside NMC office. The analysis of flat slab, flat slab without drop and grid slab done both manually by IS 456-2000 and by STAAD PRO V8i. It is found in the study that flat slab with drop is economical then rest of other considered slab for the nexus point. It is also revealed in the study that concrete required for grid slab is more than the flat slab with and without drop and steel required for the flat slab without drop is more than the flat slab with drop and grid slab.

Navjot Kaur Bhatia (June 2016) studied that dynamic performance of flat slab and grid slab in compare to conventional slab. In the study of the project the writer perform the dynamic analysis for seismic and wind forces of multistory reinforced concrete building with different plan like square, hexagonal, orthogonal for flat slab, grid slab and conventional slab. The above analysis done for different story like 10, 20 and 30 and also for the different earthquake zone as per the Indian standard code of practice is $1893-2002$. They made the relation between earthquake responses and intensities. It is revealed from the study that the performance and structural behavior of flat slab \& grid slab is superior in compare to conventional slab. It is show in term of deflection and cost of material.

D. Ramya (October 2015) analyzed the multi-story (G+10) building by both STAAD PRO V8i and ETABS software. In the study comparison between these two software is done to find out which give economy of multi storied $(\mathrm{G}+10)$ building. It is show that in the study STAAD PRO is much simple to work with as compare to ETABS software. It is also show that quantity of steel given by the ETABS is $9.25 \%$ less than by STAAD Pro when analyzed G+10 multistory building. The quantity of concrete show by both the software's is found same for multistory building. In the study it is revealed that the most economical section given by ETABS. K.N.Mate (June 2015) analyzed the flat slab .Flat slab system is simple structure of RCC which provide long clear space, a good height, simple formwork and no delay time in construction. It is shown that why the flat slab is more feasible and flexible in comparison to other slab. This study includes complete analysis and design of flat slab as per Indian code of practices IS456:2000. Flat slab is more flexible and economical as compare to conventional slab. This paper guide us how to select drop, panel width, thickness of slab and detailing of reinforcement.

\section{PROBLEM FORMULATION \& ANALYSIS}

Conventional R.C.C flat slab structure without shear wall and flat slab R.C.C structures with shear wall at particular locations are modelled and analyzed for the different combinations of static loading. Comparison is made between the conventional R.C.C flat slab structure and flat slab R.C.C. structure with shear walls situated in seismic zone

The plan area for the proposed work is $20 \times 30 \mathrm{~m}$ in which size of panels is $5 \times 5 \mathrm{~m}$. The properties of material adopted are. The Young's modulus of elasticity of concrete adopted was $25,000 \mathrm{MPa}$ while the Poisson's ratio was 0.2 . The preliminary sections of columns and beams were fixed on the basis of deflection criteria [i.e. span to depth ratio]. The sections were found to be satisfactory for the given loads for a ten storied model. These sections were maintained uniform throughout the height. Similarly, all other models of (twenty and thirty stories) were analyzed and designed to meet the current Codes (IS 456:2000 and IS 1893:2002) and their structural member sizes chosen for the study are given in table below:In the present work, the self weight of the members is calculated by considering the density as $25 \mathrm{kN} / \mathrm{m} 3$ for concrete. According to IS 456 minimum grade of concrete is M20 and grade of steel adopted is Fe415. The self weight of slab $=0.2 \times 1 \times 1$ $\mathrm{x} 25=5 \mathrm{kN} / \mathrm{m} 2$ Load considered due to floor finish $=1$ $\mathrm{kN} / \mathrm{m} 2 \mathrm{To}$ study the behaviour the response parameters selected are lateral displacement and storey drift.

All the cases are assumed to be located in zone III, 
zone IV and zone V. To reduce lateral displacement and storey drift shear walls have been provided at corners without affecting the parking in ground floors. Further, in practice multi-storey buildings are analysed by providing rigidity at various floors using master slave command in etabs software. In reality slabs exist at various floor levels which provide additional rigidity to floors. Therefore, in present work a comparative study of above mentioned practice and reality is also made. Observations show that lateral displacement and storey drift are significantly reduced by providing part shear walls.
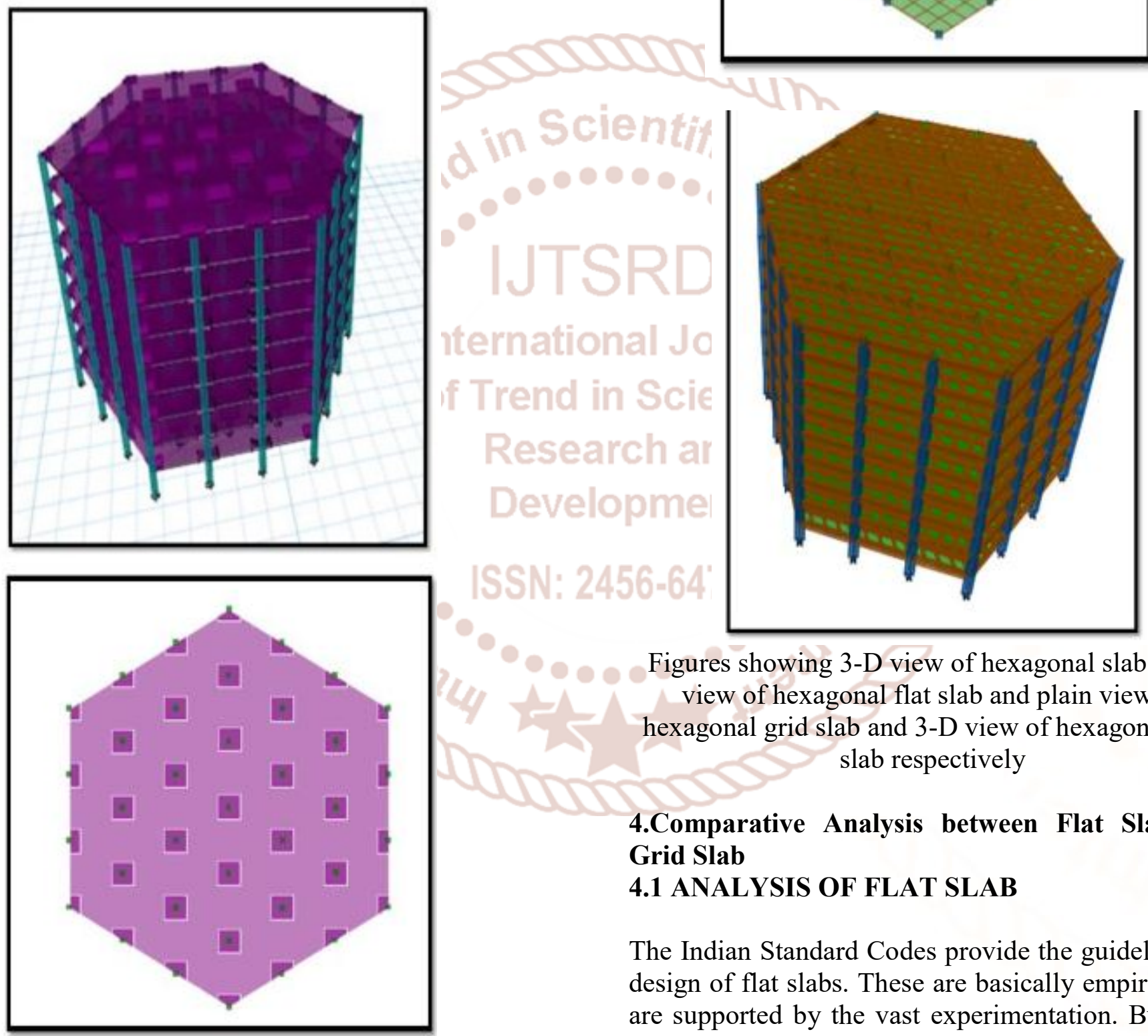

Figures showing 3-D view of hexagonal slab ,plain view of hexagonal flat slab and plain view of hexagonal grid slab and 3-D view of hexagonal grid slab respectively

\section{Comparative Analysis between Flat Slab and Grid Slab}

\subsection{ANALYSIS OF FLAT SLAB}

The Indian Standard Codes provide the guidelines for design of flat slabs. These are basically empirical and are supported by the vast experimentation. But since the standard experimentation has been done on standard layouts and configuration of the slabs, these design procedures are limited in their scope and applicability. Nowadays, irregular layouts are becoming common, and it is this light that standard codal procedures seem inadequate. Methods of analysis of flat slabs- 
International Journal of Trend in Scientific Research and Development (IJTSRD) ISSN: 2456-6470

1. Direct design method (DDM)

2. Equivalent Frame method (EFM)

3. Finite element method (FEM)

\subsection{ANALYSIS OF GRID SLAB}

For inclosing large area rooms such as theatre hall and auditoriums, where column free space is the main requirement, grid floors are used. Grids with diagonal members are called diagonal grids. Thickness of slab and edge beam of small grid can be analysed by the conventional method as in ribbed slab. Large grid floor which do not follow these restricted layouts are analysed by other methods. This method can be divided into three groups: 1 . Method based on plate theory (Approximate Methods) 2. Stiffness matrix method using computer 3. Equating deflection method of each intersecting node by simultaneous equation.

Preliminary Data for 12-story Flat slab building

\begin{tabular}{|c|c|c|}
\hline 1 & $\begin{array}{l}\text { Length in } X \text { - } \\
\text { direction }\end{array}$ & $41 \mathrm{~m}$ \\
\hline 2 & $\begin{array}{l}\text { Length in } \mathrm{Y} \text { - } \\
\text { direction }\end{array}$ & $24.6 \mathrm{~m}$ \\
\hline 3 & Floor to floor height & $3.6 \mathrm{~m}$ \\
\hline 4 & No. of Stories & 12 \\
\hline 5 & $\begin{array}{l}\text { Total height of } \\
\text { Building }\end{array}$ & $43.2 \mathrm{~m}$ \\
\hline 6 & Slab Thickness & $250 \mathrm{~mm}$ \\
\hline 7 & Drop thickness & $450 \mathrm{~mm}$ \\
\hline \multirow[t]{4}{*}{8} & \multirow[t]{4}{*}{ Size of the Column } & $\begin{array}{l}1-3 \text { story- } 950 \mathrm{mmx} x \\
950 \mathrm{~mm}\end{array}$ \\
\hline & & $\begin{array}{l}3 \cdot 6 \text { story- } 850 \mathrm{~mm} \mathrm{x} \\
850 \mathrm{~mm}\end{array}$ \\
\hline & & $\begin{array}{l}6-9 \text { story }-750 \\
m m x 750 \mathrm{~mm}\end{array}$ \\
\hline & & $\begin{array}{l}9 \cdot 12 \text { story- } 650 \\
m m x 650 \mathrm{~mm}\end{array}$ \\
\hline 9 & Grade of concrete & M25 \\
\hline
\end{tabular}

\begin{tabular}{|l|l|l|l|}
\hline 10 & Grade of Steel & \multicolumn{2}{|l|}{ Fe415 } \\
\hline 11 & Panel Dimensions & \multicolumn{2}{|l|}{$8.2 \mathrm{mx} 8.2 \mathrm{~m}$} \\
\hline 12 & \multirow{4}{*}{ Zone-II } & \multicolumn{2}{|l|}{$\begin{array}{l}\text { Soil Type 1-Rock } \\
\text { or hard soil }\end{array}$} \\
\cline { 3 - 4 } & & \multicolumn{2}{|l|}{$\begin{array}{l}\text { Soil Type 2- } \\
\text { Medium soil }\end{array}$} \\
\cline { 3 - 4 } & & $\begin{array}{l}\text { Soil Type 3-Soft } \\
\text { soil }\end{array}$ \\
\hline 13 & Loading & Terrace & Floors \\
\hline 14 & Dead load (FF) & $\begin{array}{l}1 \mathrm{KN} / \mathrm{m}^{2} \\
1 \\
\mathrm{KNN} / \mathrm{m}^{2}\end{array}$ \\
\hline 15 & Live load & $\begin{array}{l}1.5 \\
\mathrm{KN} / \mathrm{m}^{2}\end{array}$ & $3 \mathrm{KN} / \mathrm{m}^{2}$ \\
\hline 16 & Wall load & $12 \mathrm{KN} / \mathrm{m}$ & $12 \mathrm{KN} / \mathrm{m}$ \\
\hline
\end{tabular}
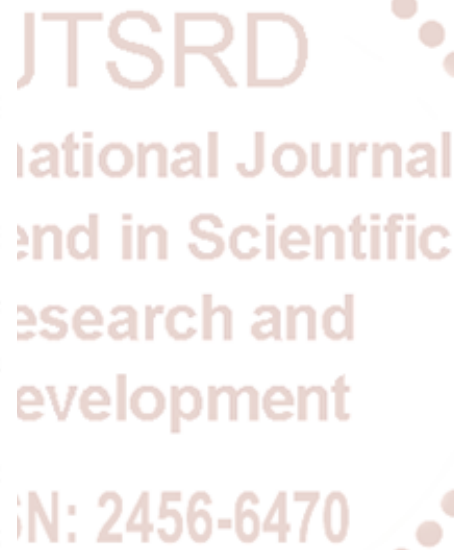
International Journal of Trend in Scientific Research and Development (IJTSRD) ISSN: 2456-6470

\begin{tabular}{|c|c|c|c|}
\hline 1 & $\begin{array}{l}\text { Length in X- } \\
\text { direction }\end{array}$ & \multicolumn{2}{|l|}{$41 \mathrm{~m}$} \\
\hline 2 & $\begin{array}{l}\text { Length in Y- } \\
\text { direction }\end{array}$ & \multicolumn{2}{|l|}{$24.6 \mathrm{~m}$} \\
\hline 3 & Floor to floor height & \multicolumn{2}{|l|}{$3.6 \mathrm{~m}$} \\
\hline 4 & No. of Stories & \multicolumn{2}{|l|}{12} \\
\hline 5 & $\begin{array}{l}\text { Total height of } \\
\text { Building }\end{array}$ & \multicolumn{2}{|l|}{$43.2 \mathrm{~m}$} \\
\hline 6 & Slab Thickness & \multicolumn{2}{|l|}{$115 \mathrm{~mm}$} \\
\hline 7 & Edge Beam & \multicolumn{2}{|c|}{$230 \mathrm{mmx} 865 \mathrm{~mm}$} \\
\hline \multirow[t]{4}{*}{8} & \multirow[t]{4}{*}{ Size of the Column } & \multicolumn{2}{|c|}{$\begin{array}{l}1-3 \text { story-950 mm x } \\
950 \mathrm{~mm}\end{array}$} \\
\hline & & \multicolumn{2}{|c|}{$\begin{array}{l}3-6 \text { story- } 850 \mathrm{~mm} \mathrm{x} \\
850 \mathrm{~mm}\end{array}$} \\
\hline & & \multicolumn{2}{|c|}{$\begin{array}{l}6-9 \text { story- } 750 \\
\mathrm{mmx} 750 \mathrm{~mm}\end{array}$} \\
\hline & & \multicolumn{2}{|c|}{$\begin{array}{l}9-12 \text { story-650 } \\
\mathrm{mm} 650 \mathrm{~mm}\end{array}$} \\
\hline 9 & Grade of concrete & \multicolumn{2}{|l|}{ M25 } \\
\hline 10 & Grade of Steel & \multicolumn{2}{|l|}{ Fe415 } \\
\hline 11 & Panel Dimensions & \multicolumn{2}{|c|}{$8.2 \mathrm{~m} \times 8.2 \mathrm{~m}$} \\
\hline 12 & Grid spacing & \multicolumn{2}{|c|}{$2.05 \mathrm{~m} \mathrm{c} / \mathrm{c}$} \\
\hline \multirow[t]{3}{*}{13} & \multirow{3}{*}{ Zone-II } & \multicolumn{2}{|c|}{$\begin{array}{l}\text { Soil Type l-Rock or } \\
\text { hard soil }\end{array}$} \\
\hline & & \multicolumn{2}{|c|}{$\begin{array}{l}\text { Soil Type 2-Medium } \\
\text { soil }\end{array}$} \\
\hline & & \multicolumn{2}{|c|}{ Soil Type 3 -Soft soil } \\
\hline 14 & Loading & Tenace & Floors \\
\hline 15 & Dead load (FF) & $1 \mathrm{KN} / \mathrm{m}^{2}$ & $1 \mathrm{KN} / \mathrm{m}^{2}$ \\
\hline 16 & Live load & $\begin{array}{l}1.5 \\
\mathrm{KN} / \mathrm{m}^{2}\end{array}$ & $3 \mathrm{KN} / \mathrm{m}^{2}$ \\
\hline 17 & Wall load & $12 \mathrm{KN} / \mathrm{m}$ & $12 \mathrm{KN} / \mathrm{m}$ \\
\hline
\end{tabular}

\section{DYNAMIC ANALYSIS}

1. For the response spectrum analysis the current code states that "at least 90 percent of the participating mass of the structure must be included in the calculation of response of each principle direction. Therefore number of modes to be evaluated must satisfy this requirement.

2. By considering 15 modes participation of flat slab and grid slab building is achieved more than $90 \%$ Therefore for all buildings 15 modes are considered.

3. Response spectrum method is used for the analysis. Importance factor and response reduction factor are considered as 1 and 3 respectively.

4. Eigen Vector analyses are used for analysis. Rigid diaphragm action is considered for analysis
5. Centre of mass \& centre of rigidity coincides, due to regularity in the plan, mass and stiffness of the building. Centre of mass \& centre of rigidity lies at (20.5m, 12.3m)

\section{Conclusion and Future Work}

1. Base shear of flat slab building is less than the base shear in grid slab building in both $\mathrm{X}$ and Y-directions.

2. Axial force in end columns of flat slab building is less as compared to grid slab building.

3. Axial force in intermediate columns of flat slab building is more as compared to grid slab building.

4. Maximum shear force is ocurs in column of story-3

5. For zone-II and soil type-II building drift in flatslab building and grid slab building is within limit in both $\mathrm{X}$ and $\mathrm{Y}$-directions.

6. Building drift in grid slab building is less as compared to flat slab building in each story in both $\mathrm{X}$ and $\mathrm{Y}$-directions.

\section{References}

1) IS 1893 (part-1) 2002 criteria for earthquake resistant design of structures. Part-1 general provision \& buildings.

2) Criteria for Earthquake Resistant Design of Structures Part 1 General Provisions and Buildings (Fifth Revision) IS 1893(part 1)2002.

3) Indian standard "Plain \& Reinforced Concrete Code of Practice" Fourth Revision IS: 456:2000.

4) Ductile Detailing of Reinforced Concrete Structures to Seismic Forces IS 13920:1993

5) M.Anitha, B.Q.Rahman, JJ.Vijay, "Analysis and Design of Flat Slabs Using Various Codes" International Institute of Information Technology, Hyderabad (Deemed University) April 2007.

6) M. H. Haraj, K. A. Soudki, and T. Kuds, "Strengthening of Interior Slab-Column Connections Using a Combination of FRP Sheets and Steel Bolts." Journal of Composites for Construction, Vol. 10, No.5, October 1, 2006.

7) M. Altug Erberik and Amr S. Elnashai "Loss Estimation Analysis of Flat-Slab Structures." Natural Hazards Review, Vol. 7, No. 1, February 1,2006 
8) B. A. Izzuddin, X. Y. Tao; and A. Y. Elghazouli, "Realistic Modeling of Composite and Reinforced Concrete Floor Slabs under Extreme Loading." I: Analytical Method Journal of Structural Engineering, Vol. 130, No. 12, December 1, 2004.

9) Dr. Ram Chandra, Virendra Gahlot, "Elements of Limit State Design of Concrete Structures" Scientific Publishers (India), 2004.

10) Durrani A. J.; Mau S. T., AbouHashish A. A., and $\mathrm{Yi} \mathrm{Li}$, "Earthquake Response of Flat-Slab Buildings," Journal of Structural Engineering, Vol. 120, No. 3, March, 1994.

11) Menon D. and S. Unnikrishna pillai "Reinforced concrete design" Book on R.C.C. Second edition, Tata McGraw hill publication.

12) Static and dynamic analysis of grid beams by “ Baishali Das".

13) S.S.Bhavikatti “Advanced R.C.C. Design (R.C.C. Volume-II).

14) Surumi R.S., Greeshma S. And Jaya K.P. (2012): Reinforced Concrete Floor Wall Slab Connection. Ijctee Issn 2249-6343 Volume 2, Issue 3.
15) Shyam Bhat M, N.A.Premanand Shenoy, Asha U Rao :( 2012) Earthquake Behaviour Of Building With And Without Shear Wall. Iset Golden Jubilee Symposium .

16) Murat Melek, Huseyin Darama, And Aysegul Gogus: (2012): Studied Effects Of Modeling Of Rc Flat Slabs On Nonlinear Response Of High Rise Building Systems.(Iosr-Jmce) E-Issn: 22781684, P-Issn: 2320-334x

17) Mohamed Abdel-Basset Abdo: (2012): Modeling Of Shear-Wall Dominant Symmetrical Flat-Plate Reinforced Concrete Buildings. 15 Wcee Lisboa 2012

18) R. P. Apostolska, G. S. Necevska-Cvetanovska, J. P.Cvetanovska And N. Mircic: (2008) Seismic Performance Of Flat Slab Building. International Journal Of Advanced Structural Engineering 2012 - The 14th World Conference On Earthquake Engineering October 12-17, 2008, Beijing, China

19) James B Daton: (2008): Design Reinforced Concrete Flat Plate Systems Based On The Results Of Finite Element Analysis. (Ijsr) 